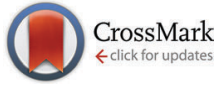

Cite this: Chem. Commun., 2015, 51, 3399

Received 22nd December 2014, Accepted 16th January 2015

DOI: $10.1039 / c 4 c c 10235 e$

www.rsc.org/chemcomm

\section{Catalytic epoxidation by perrhenate through the formation of organic-phase supramolecular ion pairs†}

\author{
Mirza Cokoja, ${ }^{\star a}$ Iulius I. E. Markovits,$\ddagger^{a}$ Michael H. Anthofer $\neq^{a}$ Saner Poplata, ${ }^{a}$ \\ Alexander Pöthig, ${ }^{a}$ Danny S. Morris, ${ }^{b}$ Peter A. Tasker, ${ }^{b}$ Wolfgang A. Herrmann, ${ }^{a}$ \\ Fritz E. Kühn ${ }^{\star^{a}}$ and Jason B. Love ${ }^{\star^{b}}$
}

\begin{abstract}
Organic-phase supramolecular ion pair (SIP) host-guest assemblies of perrhenate anions $\left(\mathrm{ReO}_{4}^{-}\right)$with ammonium amide receptor cations are reported. These compounds act as catalysts for the epoxidation of alkenes by aqueous hydrogen peroxide under biphasic conditions and can be recycled several times with no loss in activity.
\end{abstract}

The transfer of an anion into an organic phase can have enormous impact on its reactivity as the resulting hydrophobic environment accentuates supramolecular interactions between the anion, reactants, and potential substrates. ${ }^{1}$ For example, it is well known that the phase transfer of ion pairs enhances reactions of organic compounds with nucleophiles (e.g. halides, alkoxides). ${ }^{2}$ Furthermore, permanganate acts as a catalyst for the oxidation of olefins to alcohols or acids in the organic phase, ${ }^{3}$ and polyoxometallates catalyse oxidation reactions such as epoxidation under biphasic conditions. ${ }^{4}$ Unlike permanganate, the Group VII congener perrhenate is generally considered inactive in oxidation catalysis, and perrhenic acid ${ }^{5}$ or immobilized perrhenates ${ }^{6}$ act as poor epoxidation catalysts, with the nature of the active species unclear. Notably however, imidazolium perrhenates mediate the stoichiometric epoxidation of simple alkenes through the activation of $\mathrm{H}_{2} \mathrm{O}_{2}$ by hydrogen bonding to $\left[\mathrm{ReO}_{4}\right]^{-}$in a hydrophobic ionic liquid. ${ }^{7}$ Furthermore, the activity of molecular catalysts such as methyltrioxorhenium (MTO) in the biphasic epoxidation of alkenes strongly depends on the nature of the reaction medium, being highest in hydrophobic ionic liquids. ${ }^{8-10}$ Given that the transfer of $\left[\mathrm{ReO}_{4}\right]^{-}$into an organic phase has been established, ${ }^{11}$ we considered it likely that the

\footnotetext{
${ }^{a}$ Catalysis Research Center and Department of Chemistry, Technische Universität München, Lichtenbergstraße 4, 85747 Garching bei München, Germany. E-mail:mirza.cokoja@tum.de,fritz.kuehn@ch.tum.de

${ }^{b}$ EaStCHEM School of Chemistry, University of Edinburgh, David Brewster Road, Edinburgh EH9 3FJ, UK. E-mail: jason.love@ed.ac.uk

$\dagger$ Electronic supplementary information (ESI) available: Full synthetic and characterisation details of the $\left[\mathrm{HL}^{n}\right]\left[\mathrm{ReO}_{4}\right]$ compounds as well as catalysis and recycling experiments. CCDC 1030881. For ESI and crystallographic data in CIF or other electronic format see DOI: $10.1039 / \mathrm{c} 4 \mathrm{cc} 10235 \mathrm{e}$

\$ These authors contributed equally to this work.
}

amido-ammonium and -pyridinium receptors $\mathrm{L}^{1}-\mathrm{L}^{3}$ (Scheme 1), used recently in the solvent extraction of halidometalates, ${ }^{12,13}$ could be exploited to transfer $\left[\mathrm{ReO}_{4}\right]^{-}$into a hydrophobic environment; this would potentially enhance its activity in oxidation catalysis by favouring supramolecular interactions with substrates such as $\mathrm{H}_{2} \mathrm{O}_{2}$. Herein, we report the synthesis and characterization of supramolecular ion pairs (SIPs) constructed from perrhenate and the organic receptor cations $\left[\mathrm{HL}^{1}\right]^{+}-\left[\mathrm{HL}^{3}\right]^{+}$, and their application in biphasic epoxidation catalysis.

Three toluene-soluble perrhenate SIPs $\left[\mathrm{HL}^{n}\right]\left[\mathrm{ReO}_{4}\right](n=1,2,3)$ were synthesized by liquid-liquid extraction of $76.5 \mathrm{wt} \%$ perrhenic acid in water with the corresponding receptors $\mathrm{L}^{1}-\mathrm{L}^{3}$ in toluene (Scheme 1).

The compounds were analysed by ${ }^{1} \mathrm{H}$ - and ${ }^{13} \mathrm{C}-\mathrm{NMR}$ and IR spectroscopy and by elemental analysis (for details see ESI $\dagger$ ). While the SIP $\left[\mathrm{HL}^{1}\right]\left[\mathrm{ReO}_{4}\right]$ is an off-white solid, $\left[\mathrm{HL}^{2}\right]\left[\mathrm{ReO}_{4}\right]$ and $\left[\mathrm{HL}^{3}\right]\left[\mathrm{ReO}_{4}\right]$ are colourless oils at room temperature. All of the SIPs are soluble in toluene and ethers, are insoluble in aliphatic hydrocarbons, water, and $50 \% \mathrm{H}_{2} \mathrm{O}_{2}$, and decompose above $170{ }^{\circ} \mathrm{C}$, according to thermogravimetric analysis (ESI $\dagger$ ).

The solid-state structure of $\left[\mathrm{HL}^{1}\right]\left[\mathrm{ReO}_{4}\right]$ was determined by single-crystal X-ray diffraction of crystals grown from a 50/50 mixture of diethyl ether and $n$-hexane. The protonation of the receptor results in its organization due to intramolecular pyridinium-amide hydrogen bonding between the $\mathrm{N} 1$ donor and $\mathrm{O} 1 / \mathrm{O} 2$ acceptor atoms (ESI $\dagger$ ). These observations are analogous to our previous results and support the stabilisation

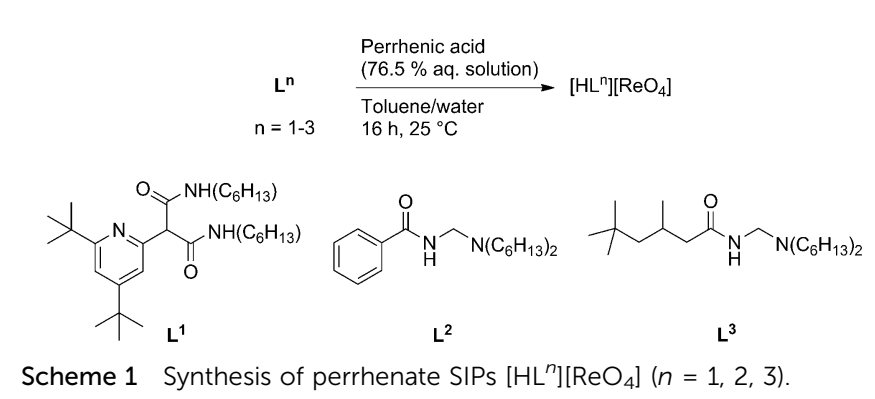




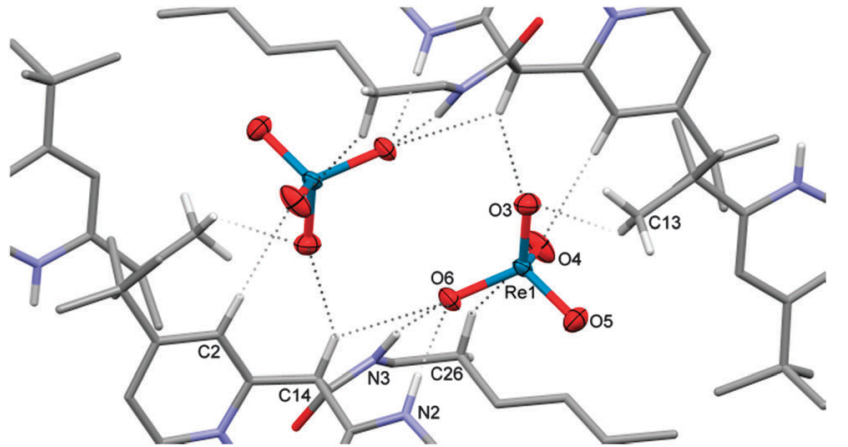

Fig. 1 The solid-state structure of $\left[\mathrm{HL}^{1}\right]\left[\mathrm{ReO}_{4}\right]$ showing the intermolecular $\mathrm{N}-\mathrm{H}$ and $\mathrm{C}-\mathrm{H}$ contacts to the perrhenate anion (displacement ellipsoids drawn at $50 \%$ probability). Bond distances (Å): Re1-O3 1.701(2),

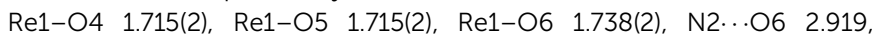

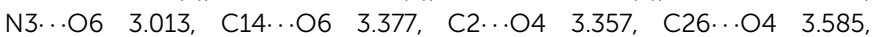

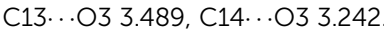

and solubilisation of the proton through a six-membered 'proton-chelate ring. ${ }^{13}$ Expansion of the structure reveals a dimeric motif in which two protonated receptors interact with two $\left[\mathrm{ReO}_{4}\right]^{-}$anions, along with a further two interactions with the ${ }^{t} \mathrm{Bu}$ protons of adjacent molecules (Fig. 1). The rigid cationic receptor offers an array of seven $\mathrm{N}$ - and C-hydrogen bonds per $\left[\mathrm{ReO}_{4}\right]^{-}$anion, with the strongest (and classical) hydrogen bonding seen between $\mathrm{N} 2-\mathrm{H}$ and $\mathrm{N} 3-\mathrm{H}$ to $\mathrm{O} 6$.

Moreover, the central $\mathrm{C} 14-\mathrm{H}$ bond of the malonamide unit bridges $\mathrm{O} 3$ and $\mathrm{O} 6$, with further intermolecular $\mathrm{C}-\mathrm{H}$ contacts to the $\mathrm{O} 3$ and $\mathrm{O} 4$ oxygen atoms of the perrhenate anion detected. These interactions lead to a distortion of the perrhenate anion from its optimal tetrahedral geometry and a distortion in the Re-oxo bond lengths, with Re1-O3 compressed and Re1-O6 elongated. These data indicate a change of the symmetry from $T_{\mathrm{d}}$ to $C_{2 \mathrm{v}}$ for the perrhenate anion in the solid state and, as such, IR studies of the SIP were undertaken to support these observations (ESI, $\dagger$ Fig. S1). After deconvolution, the spectra show three signals for the asymmetric $\mathrm{Re}=\mathrm{O}$ stretching vibration (1000-800 $\mathrm{cm}^{-1}$ ), inconsistent with $T_{\mathrm{d}}$ symmetry. In comparison to our previous studies ${ }^{7}$ the occurrence of three different signals for this vibration points to a $C_{2 \mathrm{v}}$ symmetric $\left[\mathrm{ReO}_{4}\right]^{-}$anion, corroborating the above observations.

The solution structures of the perrhenate SIPs were probed using ESI-MS and NMR techniques. No ions are seen in the ESI-MS for samples dissolved in toluene so experiments were carried out using $\mathrm{CH}_{3} \mathrm{CN}$ as the diluent and at low inlet nozzle temperatures $\left(50{ }^{\circ} \mathrm{C}\right)$. The ESI-MS of $\left[\mathrm{HL}^{1}\right]\left[\mathrm{ReO}_{4}\right]$ (Fig. 2) shows no ions that correlate with the X-ray crystal structure. However, the formation of aggregated assemblies is apparent, with the parent ion at $920 \mathrm{amu}$ resulting from the pairing of $\left[\mathrm{HL}^{1}\right]^{+}$with $\mathrm{L}^{1}$. Furthermore, ions due to single or double perrhenate incorporation in assemblies of protonated and/or neutral receptors are seen at 1171,1631 , and 1883 amu. While these data do not correlate with the dinuclear structural motif identified in the solid state, it is clear that host-guest assemblies are formed in solution. For $\left[\mathrm{HL}^{2}\right]\left[\mathrm{ReO}_{4}\right]$ and $\left[\mathrm{HL}^{3}\right]\left[\mathrm{ReO}_{4}\right]$ in $\mathrm{CH}_{3} \mathrm{CN}$ (ESI, $\dagger$ Fig. S14 and S15), similar patterns are seen,

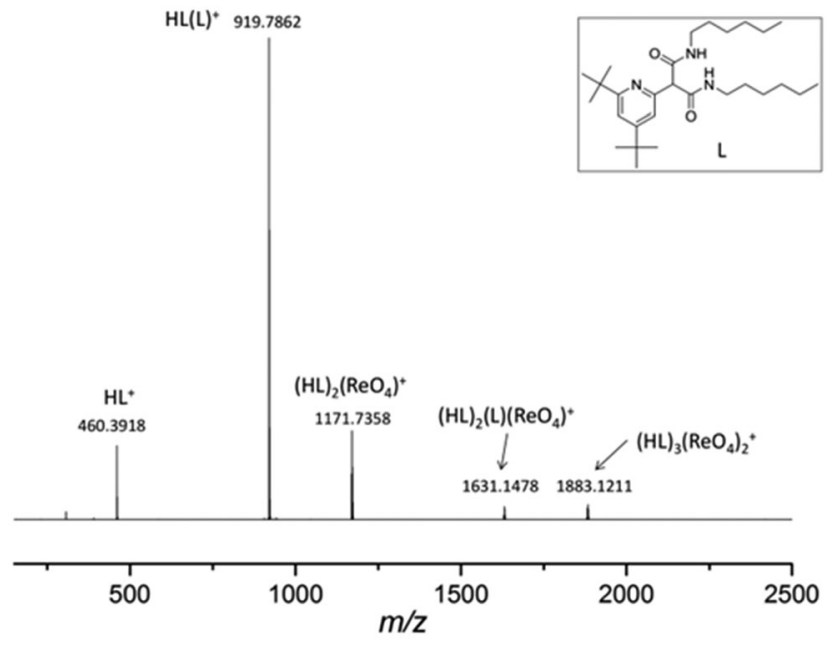

Fig. 2 ESI-MS of $\left[\mathrm{HL}^{1}\right]\left[\mathrm{ReO}_{4}\right]$ in $\mathrm{CH}_{3} \mathrm{CN}$.

but in these cases facile fragmentation of the receptor at the bridging methylene group is observed, resulting in more complex spectra.

The formation of an organised receptor on protonation is further supported by the ${ }^{1} \mathrm{H}-\mathrm{NMR}$ spectrum of $\left[\mathrm{HL}^{1}\right]\left[\mathrm{ReO}_{4}\right]$ in $\mathrm{CDCl}_{3}$ which shows a new peak at $14.66 \mathrm{ppm}$ for the pyridinium $\mathrm{NH}$ proton and all other protons shifted to higher frequency with the $\mathrm{NCH}_{2}(3.18 \mathrm{ppm})$ resonances of the hexylamine chains split into two; similar features were reported for the analogue $\left[\mathrm{HL}^{1}\right]_{2}\left[\mathrm{ZnCl}_{4}\right]^{13}$ As with the above ESI-MS data, the ${ }^{1} \mathrm{H}$ NMR spectrum of $\left[\mathrm{HL}^{3}\right]\left[\mathrm{ReO}_{4}\right]$ indicates that some fragmentation of the receptor has occurred, with broad resonances at 7.9 and 6.5/5.9 ppm assignable to the separate ammonium and amide constituents of $\mathrm{HL}^{3}$ along with those due to the intact SIP. All three SIPs were analysed using DOSY NMR spectroscopy (ESI, $\dagger$ Fig. S5-S10). In $\mathrm{C}_{6} \mathrm{D}_{6}$, a single species is observed for $\left[\mathrm{HL}^{1}\right]\left[\mathrm{ReO}_{4}\right]$ with a calculated hydrodynamic radius of $c a$. $6.3 \AA$, larger than that of the free ligand and consistent with a degree of aggregation in solution. Similarly, for $\left[\mathrm{HL}^{n}\right]\left[\mathrm{ReO}_{4}\right](n=2,3)$ in $\mathrm{C}_{6} \mathrm{D}_{6}$ single species with radii of $c a$. 6.6 and $6.7 \AA$, respectively are seen. In $\mathrm{CH}_{3} \mathrm{CN}$, several species are observed for $\left[\mathrm{HL}^{n}\right]\left[\mathrm{ReO}_{4}\right]$ with radii varying between $c a .2 .8$ and $4.5 \AA$, indicating that more dynamic speciation occurs in this more polar solvent. It is therefore likely that the aggregated structure seen in the solid state is representative of the structures of the SIPs in non-polar solvents such as toluene.

The SIPs were used as catalysts for the two-phase epoxidation of cyclooctene with aqueous hydrogen peroxide $(50 \%)$ without additional solvents. All of the SIPs are active catalysts, leading to nearly quantitative conversions of cyclooctene after 6-8 h reaction time at $70{ }^{\circ} \mathrm{C}$ (Fig. 3 ), with quantitative selectivity for epoxide, i.e. the possible by-product 1,2-cyclooctanediol is not formed. Significantly, in the absence of perrhenate conversion to the epoxide does not occur. This is the first example of the application of perrhenate as an epoxidation catalyst in an organic phase, resulting from its transfer from the aqueous phase into the hydrophobic medium. Significantly, under similar oxidative reaction conditions, other typical phase transfer agents 


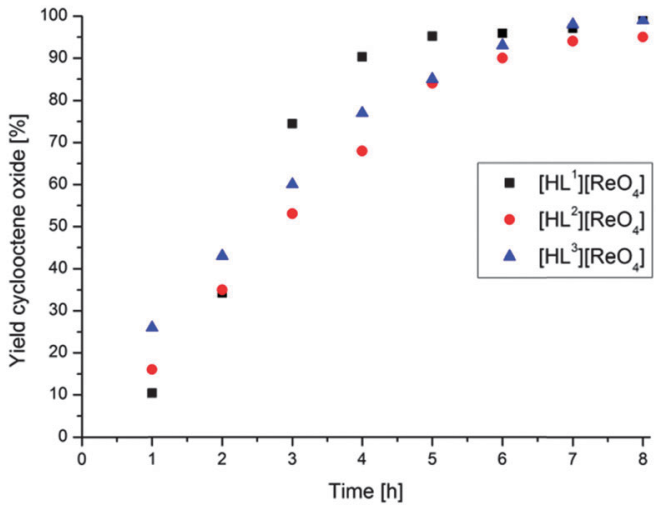

Fig. 3 Kinetic plots of the epoxidation of cyclooctene using catalysts [HL $\left.{ }^{n}\right]\left[\mathrm{ReO}_{4}\right](n=1-3)$ and aqueous $\mathrm{H}_{2} \mathrm{O}_{2}$ as oxidant. Reaction conditions: $70{ }^{\circ} \mathrm{C}, 5 \mathrm{~mol} \%$ catalyst, molar ratio catalyst : substrate : oxidant $5: 100: 250$.

such as crown ethers decompose, and quaternary ammonium salts are inactive. At the start of the reaction, $\left[\mathrm{HL}^{2}\right]\left[\mathrm{ReO}_{4}\right]$ and $\left[\mathrm{HL}^{3}\right]\left[\mathrm{ReO}_{4}\right]$ are more active than $\left[\mathrm{HL}^{1}\right]\left[\mathrm{ReO}_{4}\right]$ presumably because of their higher hydrophobicity. However, both $\left[\mathrm{HL}^{2}\right]$ and $\left[\mathrm{HL}^{3}\right]$ receptors are already partially fragmented during the SIP synthesis, and in presence of hydrogen peroxide they decompose entirely, which may be a reason for the decreasing activity over time. Hence, further catalytic investigations were carried out using $\left[\mathrm{HL}^{1}\right]\left[\mathrm{ReO}_{4}\right]$, which is the only SIP stable under oxidative (catalytic) conditions (ESI, $\uparrow$ Fig. S11 and S12). While the other SIPs comprise mixtures of the fragmented cation (amide and ammonium), perrhenate, and intact $\left[\mathrm{HL}^{n}\right]\left[\mathrm{ReO}_{4}\right](n=2,3)$ they are, however, still catalytically active, albeit to a lesser extent than $\left[\mathrm{HL}^{1}\right]\left[\mathrm{ReO}_{4}\right]$.

The reaction temperature has a significant effect on the catalyst activity (ESI, $\dagger$ Fig. S19). At $50{ }^{\circ} \mathrm{C}$ the yield of cyclooctene oxide is $33 \%$ after $6 \mathrm{~h}$, in contrast to $100 \%$ conversion at $70{ }^{\circ} \mathrm{C}$ over the same time period; at $25{ }^{\circ} \mathrm{C}$, no conversion is seen. Reducing the catalyst loading to 1 or $2.5 \mathrm{~mol} \%$ also results in a lower conversion of cyclooctene with 34 and $80 \%$ conversions after $6 \mathrm{~h}$, respectively, compared to $92 \%$ using 5 mol\% loadings (ESI, $\dagger$ Fig. S20). Increasing the amount of oxidant has no effect on the catalytic activity of the SIPs (ESI, $\uparrow$ Fig. S21). We have no indication for partial decomposition of $\mathrm{H}_{2} \mathrm{O}_{2}$ at these temperatures. When less than 1 equiv. $\mathrm{H}_{2} \mathrm{O}_{2}$ per cyclooctene is used, the conversion corresponds to the $\mathrm{H}_{2} \mathrm{O}_{2}$ consumed, yet the reaction is slower. Adding toluene to the reaction mixture increases the solubility of the catalyst in the organic phase, ensuring that the catalyst is dissolved even at decreasing cyclooctene concentrations. Monitoring the epoxidation of cyclooctene during an eight-hour reaction (ESI, $\dagger$ Fig. S22) confirms that the addition of toluene does not diminish activity and conversion compared to the neat reaction.

Based on our previous work and DFT calculations, ${ }^{7}$ the transfer of perrhenate from the aqueous to hydrophobic organic phase should activate $\mathrm{H}_{2} \mathrm{O}_{2}$ through H-bonding interactions, which in turn favours oxygen transfer to an olefin (Scheme 2). While we have not yet carried out DFT calculations on this current system, spectroscopic data suggest that a similar

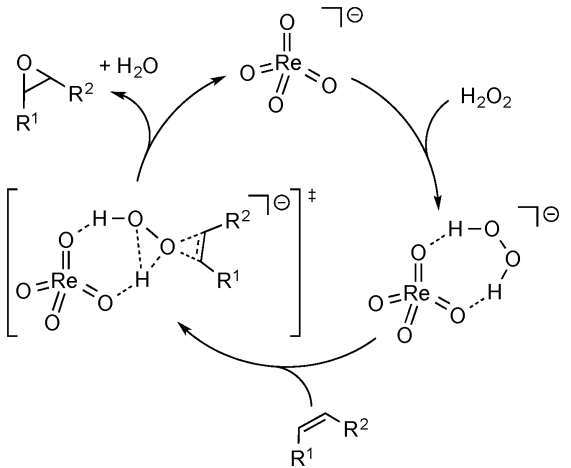

Scheme 2 Mechanism of the epoxidation of olefins catalysed by the perrhenate ion in ILs. ${ }^{7}$

mechanism operates. When ${ }^{17} \mathrm{O}$-labelled $\left[\mathrm{HL}^{1}\right]\left[\mathrm{Re}^{17} \mathrm{O}_{4}\right]$ catalyst is used for the epoxidation of cyclooctene no ${ }^{17} \mathrm{O}$ is seen in the ${ }^{17} \mathrm{O}$-NMR spectrum of the isolated cyclooctene oxide (ESI, $\dagger$ Fig. S13). This indicates that the oxygen transfer to the olefin does not originate from a $\mathrm{Re}-\mathrm{O}$ species, but rather from an outer-sphere activation of $\mathrm{H}_{2} \mathrm{O}_{2}$, as shown in Scheme 2. Note that both the neutral receptor $\mathrm{L}^{1}$ and protonated $\left[\mathrm{HL}^{1}\right][\mathrm{Br}]$ do not exhibit catalytic activity under the applied reaction conditions (ESI, $\dagger$ Fig. S24), so the activity of the SIP can only be ascribed to the presence of perrhenate.

Importantly, the biphasic system consisting of water $/ \mathrm{H}_{2} \mathrm{O}_{2}$ and toluene/SIP/product facilitates the catalyst-product separation. The SIP catalyst and the product are extracted with toluene, and subsequent distillation of the solvent and product recovers the SIP. Leaching of the SIP catalyst into the aqueous phase does not occur; phase separation after $2.5 \mathrm{~h}$ reaction time ( $c a .50 \%$ conversion of cyclooctene, see Fig. 3) and addition of fresh cyclooctene to the aqueous phase did not lead to further epoxide formation. As such, this procedure allows for catalyst reusability, rendering these supramolecular catalysts suitable for larger scale applications. Indeed, the $\operatorname{SIP}\left[\mathrm{HL}^{1}\right]\left[\mathrm{ReO}_{4}\right]$ was recycled five times after $4 \mathrm{~h}$ reaction time and displayed no loss in activity within the error range of the data analyses (ESI, $\dagger$ Fig. S23).

To demonstrate the generality of these catalysts, we have studied the epoxidation of other alkenes, and, in nearly all cases investigated, good conversions are reached (Table 1). It is known that terminal alkenes, such as 1-octene and styrene are

Table 1 Epoxidation of alkenes using the SIP $\left[\mathrm{HL}^{1}\right]\left[\mathrm{ReO}_{4}\right]$ as catalyst

$$
\mathrm{R}^{1} \underset{\mathrm{R}^{2}}{\stackrel{\substack{\text { SIP cat. } \\ \text { I mol \% } \%}}{\longrightarrow} \mathrm{H}_{2} \mathrm{O}_{2}} \mathrm{R}^{1} \gtrless_{\mathrm{R}^{2}}^{\mathrm{O}}
$$

\begin{tabular}{llll}
\hline Entry & Substrate & Conv. [\%] & Sel. [\%] \\
\hline 1 & Cyclohexene & 89 & 99 \\
2 & 1-Octene & 77 & 24 \\
3 & Styrene & 70 & 44 \\
4 & Allyl alcohol & 84 & 18 \\
5 & Propene & 16 & 50
\end{tabular}

Reaction conditions: 5 mol\% catalyst, aq. $\mathrm{H}_{2} \mathrm{O}_{2}$ as oxidant, molar cat: substrate: oxidant ratio $5: 100: 250,8 \mathrm{~h}, 70{ }^{\circ} \mathrm{C}$. 
intrinsically more difficult to epoxidise than (cyclic) cis-alkenes and the ring opening of the products to diols (the only byproduct) is, in these cases, facilitated due to steric reasons. ${ }^{8,9}$ Even though the overall performance obtained with the SIP catalysts is lower than that of known molecular epoxidation catalysts such as MTO $\left(\mathrm{TOF}_{\max }=39000 \mathrm{~h}^{-1}\right.$ for cyclooctene as substrate at $\left.0{ }^{\circ} \mathrm{C}\right),{ }^{9,14-16}$ the SIPs exhibit the advantage of being more stable and recyclable; at $70{ }^{\circ} \mathrm{C}$ the catalytically active species formed from MTO and $\mathrm{H}_{2} \mathrm{O}_{2}$ decomposes rapidly. ${ }^{16}$

It is noteworthy that the epoxidation of allyl alcohol leads to a good conversion, yet low selectivity. This is likely due to the good miscibility of the epoxide product in water, which leads to over-oxidation and the formation of glycerol. Also, the SIPs catalyse the epoxidation of propene to propene oxide (PO). Although the conversion is low, it should be noted that there are only a few reports on propene epoxidation using molecular catalysts, all of which display similar conversions. ${ }^{5}$ In this case, although the catalytic performance of the SIP is lower than that of MTO, the system presented here is recyclable and so the SIPS outcompete MTO in the long term.

The transfer of the perrhenate anion into a hydrophobic medium enhances its supramolecular interactions, resulting in very robust and active catalysts for biphasic alkene epoxidation by hydrogen peroxide. This is the first report on the epoxidation of alkenes catalysed by perrhenate in organic solvents and exploits the concept of transferring compounds regarded as notoriously inactive in catalysis into an organic phase to significantly enhance catalytic performance. Furthermore, the back-transfer of the anion allows for straightforward separation and recovery of the catalyst, which clearly outperforms other immobilized molecular catalysts, so offering a simple, sustainable alternative to established molecular catalysts.

\section{Notes and references}

1 M. Raynal, P. Ballester, A. Vidal-Ferran and P. W. N. M. van Leeuwen, Chem. Soc. Rev., 2014, 43, 1660; M. Raynal, P. Ballester, A. VidalFerran and P. W. N. M. van Leeuwen, Chem. Soc. Rev., 2014, 43, 1734; K. Brak and E. N. Jacobsen, Angew. Chem., Int. Ed., 2013, 52, 534;
T. Ooi and K. Maruoka, Angew. Chem., Int. Ed., 2007, 46, 4222; J. W. Steed and J. L. Atwood, Supramolecular Chemistry., John Wiley \& Sons, Chichester, UK, 2009; R. Breslow and L. E. Overman, J. Am. Chem. Soc., 1970, 92, 1075; S. Beckendorf, S. Asmus and O. García Mancheño, ChemCatChem, 2012, 4, 926.

2 C. L. Liotta and H. P. Harris, J. Am. Chem. Soc., 1974, 96, 2250; E. V. Dehmlow, Angew. Chem., Int. Ed., 1977, 16, 493; P. Viout, J. Mol. Catal., 1981, 10, 231; J.-F. Brière, S. Oudeyer, V. Dalla and V. Levacher, Chem. Soc. Rev., 2012, 41, 1696.

3 D. J. Sam and H. E. Simmons, J. Am. Chem. Soc., 1972, 94, 4024.

4 G. De Faveri, G. Ilyashenko and M. Watkinson, Chem. Soc. Rev., 2011, 40, 1722; R. H. Ingle and N. K. K. Raj, J. Mol. Catal. A: Chem., 2008, 294, 8; M. Bösing, A. Nöh, I. Loose and B. Krebs, J. Am. Chem. Soc., 1998, 120, 7252; K. Sato, M. Aoki and R. Noyori, Science, 1998, 281, 1646.

5 M. C. A. van Vliet, I. W. C. E. Arends and R. A. Sheldon, J. Chem. Soc., Perkin Trans. 1, 2000, 377.

6 D. Mandelli, M. C. A. van Vliet, U. Arnold, R. A. Sheldon and U. Schuchardt, J. Mol. Catal. A: Chem., 2001, 168, 165; D. Veljanovski, A. Sakthivel, W. A. Herrmann and F. E. Kühn, Adv. Synth. Catal., 2006, 348, 1752.

7 I. I. E. Markovits, W. A. Eger, S. Yue, M. Cokoja, C. J. Münchmeyer, B. Zhang, M.-D. Zhou, A. Genest, J. Mink, S.-L. Zang, N. Rösch and F. E. Kühn, Chem. - Eur. J., 2013, 19, 5972.

8 S. Huber, M. Cokoja and F. E. Kühn, J. Organomet. Chem., 2014, $751,25$.

9 S. A. Hauser, M. Cokoja and F. E. Kühn, Catal. Sci. Technol., 2013, 3, 552.

10 D. Betz, A. Raith, M. Cokoja and F. E. Kühn, ChemSusChem, 2010, 3, 559.

11 E. A. Katayev, G. V. Kolesnikov and J. L. Sessler, Chem. Soc. Rev., 2009, 38, 1572; M. Saeki, Y. Sasaki, A. Nakai, A. Ohashi, D. Banerjee, A. C. Scheinost and H. Foerstendorf, Inorg. Chem., 2012, 51, 5814.

12 R. J. Ellis, J. Chartres, D. K. Henderson, R. Cabot, P. R. Richardson, F. J. White, M. Schröder, J. R. Turkington, P. A. Tasker and K. C. Sole, Chem. - Eur. J., 2012, 18, 7715; J. R. Turkington, P. J. Bailey, J. B. Love, A. M. Wilson and P. A. Tasker, Chem. Commun., 2013, 49, 1891; A. M. Wilson, P. J. Bailey, P. A. Tasker, J. R. Turkington, R. A. Grant and J. B. Love, Chem. Soc. Rev., 2014, 43, 123.

13 J. R. Turkington, V. Cocalia, K. Kendall, C. A. Morrison, P. Richardson, T. Sassi, P. A. Tasker, P. J. Bailey and K. C. Sole, Inorg. Chem., 2012, $51,12805$.

14 I. I. E. Markovits, M. H. Anthofer, H. Kolding, M. Cokoja, A. Pöthig, A. Raba, W. A. Herrmann, R. Fehrmann and F. E. Kühn, Catal. Sci. Technol., 2014, 4, 3845.

15 H.-J. Lee, T.-P. Shi, D. H. Busch and B. Subramaniam, Chem. Eng. Sci., 2007, 62, 7282 .

16 P. Altmann, M. Cokoja and F. E. Kühn, Eur. J. Inorg. Chem., 2012, 3235-3239; F. E. Kühn, A. Scherbaum and W. A. Herrmann, J. Organomet. Chem., 2004, 689, 4149. 